Table

\begin{tabular}{lcccc}
\hline & $\begin{array}{c}\text { Disease } \\
\text { duration }\end{array}$ & $\begin{array}{c}\text { Uric acid } \\
\mu \mathrm{mol} / \mathrm{L}\end{array}$ & $\begin{array}{c}\text { Creatinine } \\
\mu \mathrm{mol} / \mathrm{L}\end{array}$ & $\begin{array}{c}\text { Creatinine } \\
\mu \mathrm{mol} / \mathrm{L}\end{array}$ \\
\hline Sum score DC & $0.35^{\star *}$ & $0.30^{\star *}$ & $0.26^{* *}$ & $-0.27^{\star *}$ \\
Sum score tophi & $0.27^{* *}$ & 0.13 & $0.27^{* *}$ & $-0.37^{\star *}$ \\
Sum score aggregates & $0.16^{*}$ & 0.05 & $0.22^{*}$ & $-0.36^{\star *}$ \\
Sum score DC, tophi and & $0.29^{* *}$ & $0.16^{*}$ & $0.29^{* *}$ & $-0.40^{* *}$ \\
aggregates & & & & \\
\hline
\end{tabular}

Table 2. Percentages of patients with different forms of ultrasound detected uric acid deposits

\begin{tabular}{lcccccc}
\hline & \multicolumn{2}{c}{ Double contour } & \multicolumn{2}{c}{ Tophus } & \multicolumn{2}{c}{ Aggregates } \\
\hline & Right & Left & Right & Left & Right & Left \\
\hline Wrist & 1.5 & 0.5 & 7.0 & 8.5 & 6.0 & 7.0 \\
MCP 2 & 2.0 & 1.0 & 5.0 & 2.5 & 4.0 & 3.0 \\
Distal femur cartilage & 16.9 & 16.9 & NA & NA & NA & NA \\
Talar cartilage & 15.4 & 16.9 & NA & NA & NA & NA \\
MTP 1 & 36.0 & 35.8 & 44.0 & 45.5 & 51.5 & 50.3 \\
Triceps & NA & NA & 15.0 & 12.5 & 32.8 & 31.8 \\
Quadriceps & NA & NA & 5.5 & 8.0 & 10.1 & 15.9 \\
Proximal patellar tendon & NA & NA & 5.0 & 7.0 & 9.5 & 13.4 \\
Distal patellar tendon & NA & NA & 19.5 & 15.0 & 42.5 & 37.3 \\
Achilles & NA & NA & 9.5 & 8.0 & 12.1 & 6.0 \\
\hline & & & & & &
\end{tabular}

Disclosure of Interests: Hilde Berner Hammer Grant/research support from: AbbVie, Pfizer and Roche, Paid instructor for: AbbVie, Pfizer, UCB, Novartis, Roche, Speakers bureau: AbbVie, Pfizer, UCB, Novartis, Roche, Lars Fridtjof Karoliussen: None declared, Lene Terslev Speakers bureau: Speakers fee from : Roche, Novartis, Pfizer, MSD, BMS, Celgene, Tore K. Kvien Grant/research support from: AbbVie, BMS, MSD, Pfizer, Roche and UCB., Consultant for: AbbVie, Biogen, BMS, Boehringer Ingelheim, Celgene, Celltrion, Eli Lilly, Hospira, Merck-Serono, MSD, Novartis, Oktal, Orion Pharma, Pfizer, Roche, Sandoz, Sanofi, Mylan and UCB, Speakers bureau: AbbVie, Biogen, BMS, Boehringer Ingelheim, Celgene, Celltrion, Eli Lilly, Hospira, Merck-Serono, MSD, Novartis, Oktal, Orion Pharma, Pfizer, Roche, Sandoz, Sanofi and UCB, Till Uhlig Consultant for: Grünenthal, Novartis, Speakers bureau: Grünenthal, Novartis

DOI: 10.1136/annrheumdis-2019-eular.3523

\section{SAT0424 PHENOTYPE OF PATIENTS WITH EARLY ONSET GOUT}

Julia Herrou, Omar Al Tabaa, Etienne Gaix-Fontaine, Pascal Richette,

Thomas Bardin, Frederic Lioté, Aline Frazier, Hang Korng Ea. Hôpital Lariboisière, Paris, France

Background: Gout is a frequent inflammatory arthritis in men after 45 years old. In this common (CG) form, gout is associated with comorbidities (CMs) including metabolic syndrome, hypertension, type 2 diabetes (T2D), obesity, chronic kidney disease and cardiovascular (CV) diseases. In contrast, very few data are available for early onset gout (EOG), defined as first flare before 30 years old.

Objectives: The aim of this study was to compare gout characteristics and CMs between EOG and CG.

Methods: We retrospectively included all gout patients (pts) with ineffective ULT who were referred to our department between 2014 and 2018, and who had at least one visit between 9 and 15 months after first visit. At baseline, ineffective ULT was defined by a serum urate level (SUL) above target (> $360 \mu \mathrm{mol} / \mathrm{L}$ ). Demographic characteristics, gout history and $\mathrm{CMs}$, treatments were systematically recorded.

Results: Among 213 pts, $39(18.3 \%)$ had experienced a first gout flare before 30 years old. Pts and gout characteristics are summarized in table 1. Mean age of first flare in EOG was 24.8 ( \pm 5.5 ) years. Familial history of gout was more frequent in EOG than in CG (60.6 vs 24.6\%). First flare involved the $1^{\text {st }}$ metatarsophalangeal joint in $70 \%$ of EOG pts. EOG pts had more severe gout than CG pts: longer disease duration $(p<0.0001)$, more flares in the last 12 months $(p<0.0001)$, more tophi $(p=0.005)$ and higher febuxostat $(F B X)$ dosage $(p=0.02)$ to achieve SUL target.
Pts with CG had more CMs than EOG pts: CV diseases, hypertension, T2D, dyslipidemia and kidney transplantation. Non-alcoholic fatty liver disease was more frequent in EOG than CG (61.1 vs $24.1 \%$ ).

At final visit, 62.8 and $67.9 \%$ of EOG and CG patients, respectively, achieved SUL target $(p=0.56)$. Proportion of pts taken ULT was similar in both groups as well as proportion of pts treated with allopurinol or FBX.

Table 1. Patient characteristics between early onset and common gout

\begin{tabular}{|c|c|c|c|}
\hline Variables & $\begin{array}{l}\text { Early onset gout } \\
(\mathrm{N}=39)\end{array}$ & $\begin{array}{l}\text { Common gout } \\
(\mathrm{N}=174)\end{array}$ & $\mathrm{p}$ \\
\hline $\begin{array}{l}\text { Age at inclusion (years), (mean } \pm \\
\text { SD) }\end{array}$ & $40.2(12.2)$ & $62.2(11.8)$ & $<0.0001$ \\
\hline Sex (male) & $38(97.4 \%)$ & $145(83.3 \%)$ & 0.02 \\
\hline BMI $\left(\mathrm{kg} / \mathrm{m}^{2}\right),($ mean $\pm \mathrm{SD})$ & $29.6(5.8)$ & $28.9(4.9)$ & 0.49 \\
\hline Family history $(n, \%)$ & $20(60.6 \%)$ & $30(24.6 \%)$ & $<0.0001$ \\
\hline $\begin{array}{l}\text { Age at first flare (years), mean } \pm \\
\text { SD) }\end{array}$ & $24.8(6.2)$ & $55.4(12.6)$ & $<0.0001$ \\
\hline $\begin{array}{l}\text { Disease duration (years) (mean } \pm \\
\text { SD) }\end{array}$ & $15.4(12.6)$ & $6.9(7.6)$ & $<0.0001$ \\
\hline Tophi (n,\%) & $24(61.5 \%)$ & $58(36.9 \%)$ & 0.005 \\
\hline Urate arthropathy $(n, \%)$ & $21(65.6 \%)$ & $61(49.6 \%)$ & 0.11 \\
\hline $\begin{array}{l}\text { Number of flares last } 12 \text { months } \\
\text { (mean } \pm \text { SD) }\end{array}$ & $4.7(2.9)$ & $3.0(2.82)$ & 0.009 \\
\hline eGFR $(\mathrm{ml} / \mathrm{min} / 1.73),($ mean $\pm \mathrm{SD})$ & $91.7(33.4)$ & $63.4(24.5)$ & $<0.0001$ \\
\hline Baseline SUL $(\mu \mathrm{mol} / \mathrm{l})($ mean $\pm \mathrm{SD})$ & $495.9(147.4)$ & $521.1(109.1)$ & 0.23 \\
\hline CV diseases $(n, \%)$ & 0 & $21(13.2 \%)$ & 0.02 \\
\hline HT $(n, \%)$ & $9(23.7 \%)$ & $107(64.8 \%)$ & $<0.0001$ \\
\hline Type 2 diabetes $(n, \%)$ & $3(7.9 \%)$ & $41(25.3 \%)$ & 0.02 \\
\hline $\operatorname{NAFLD}(\mathrm{n}, \%)$ & $11(61.1 \%)$ & $14(24.1 \%)$ & 0.003 \\
\hline Dyslipidemia (n,\%) & $13(33.3 \%)$ & $70(45.5 \%)$ & 0.17 \\
\hline $\begin{array}{l}\text { Chronic kidney disease stage } 3-5 \text { (n, } \\
\%)\end{array}$ & $8(25.8 \%)$ & $58(40.6 \%)$ & 0.12 \\
\hline Final SUL $(\mu \mathrm{mol} / \mathrm{l})($ mean $\pm \mathrm{SD})$ & 360.7 (135.5) & $336.6(109.9)$ & 0.26 \\
\hline SUL at target $(<360 \mu \mathrm{mol} / \mathrm{l})(\mathrm{n}, \%)$ & $22(62.8 \%)$ & $110(67.9 \%)$ & 0.56 \\
\hline ULT final $(n, \%)$ & $36(92.3 \%)$ & $148(92.5)$ & 0.97 \\
\hline
\end{tabular}

(148

fatty liver disease; SUL : serum urate level; ULT : urate-lowering therapy

Conclusion: In conclusion, EOG is more severe and EOG pts have less CMs. Moreover, EOG has a higher inheritability trait than CG patients suggesting different pathological mechanisms.

Disclosure of Interests: Julia Herrou: None declared, Omar Al Tabaa: None declared, Etienne Gaix-Fontaine: None declared, Pascal Richette Consultant for: Grunenthal, Horizon, Speakers bureau: AstraZeneca, Grunenthal, Thomas Bardin Consultant for: Astrazeneca, Grunenthal, Horizon, Novartis, Speakers bureau: Astella, AstraZeneca, Grunenthal., Frederic Lioté Grant/research support from: institutional grants from Grunenthal, Ipsen Pharma/Menarini, Novartis, SOBI for the European Crystal Network Workshops, Consultant for: Grunenthal, Novartis, Aline Frazier: None declared, Hang Korng Ea: None declared

DOI: 10.1136/annrheumdis-2019-eular 5614

\section{SAT0425 CLINICAL CHARACTERISTICS AND RISK FACTORS OF ULCERATION OVER TOPHI IN PATIENTS WITH GOUT}

Zhengping Huang, Xiuqi Liu, Yuqi Liu, LI Tianwang. Guangdong Second Provincial General Hospital, Guangzhou, China

Background: With increasing prevalence of gout world-wide, ulceration associated with tophaceous gout is becoming increasingly common in recent years. Investigation of the clinical characteristics and risk factors will allow us to better understand the fact of ulceration over tophi and improve the management for such challenge problem.

Objectives: To describe clinical characteristics of ulceration over tophi in patients with gout and determine risk factors associated with ulceration. Methods: Patients presenting with tophi or ulceration(s) over tophi were prospectively recruited and their clinical characteristics were recorded Comparison of clinical characteristics and risk factors for ulceration were analyzed between groups. 
Results: A total of 105 patients were enrolled. 33 patients with ulcerations were older, with prolonged duration with gout and tophi, a higher rate of obesity, greater number of tophi, lower level of GFR, and higher level of serum creatinine, ESR and CRP. The mean duration of ulceration was $1.63 \pm 2.32$ months. The ulcerations mainly located in ankle $(34.21 \%)$ and MTP (39.47\%), with a mean size of $32.37 \times 22.76 \mathrm{~mm}$. The majority of ulcerations were categorized as stage I (42.4\%) and stage II (51.5\%). In univariate regression analysis, age, glucocorticoid abuse, gout duration, tophi duration, tophi number and GFR were associated with ulceration. In the multivariable model, significant differences were demonstrated in glucocorticoid abuse, tophi duration, tophi number. Conclusion: Gout patients with ulceration(s) over tophi present several different aspects of clinical characteristics compared with those without ulceration. Glucocorticoid abuse, prolonged duration with tophi and greater number of tophi are risk factors for ulceration over tophi. Avoiding indiscriminate use of glucocorticoid needs to be emphasized, and prevention of tophi formation via initiate effective urate-lowering therapy is highly recommended in patients with gout.

\section{REFERENCES}

[1] Lam G, Ross FL, Chiu ES. Nonhealing Ulcers in Patients with Tophaceous Gout: A Systematic Review. Adv Skin Wound Care. May 2017;30(5):230237.

Disclosure of Interests: None declared

DOI: 10.1136/annrheumdis-2019-eular.2607

\section{SAT0426 1 TOPHI, THE PREDICTIVE FACTOR OF ARTERIAL STIFFNESS IN PATIENTSWITH GOUT AND HYPERURICEMIA}

WooSeong Jeong ${ }^{1}$, Jinseok $\mathrm{Kim}^{2}$, Joonhyouk Choi ${ }^{2} .{ }^{1}$ Jeju National University Hospital, Jeju, Korea, Rep. of (South Korea); ' Jeju National University School of Medicine, Jeju, Korea, Rep. of (South Korea)

Background: Gout is the most common form of inflammatory arthritis and its prevalence is increasing in recent decades. Many studies have reported that gout and hyperuricemia are associated with an increase in

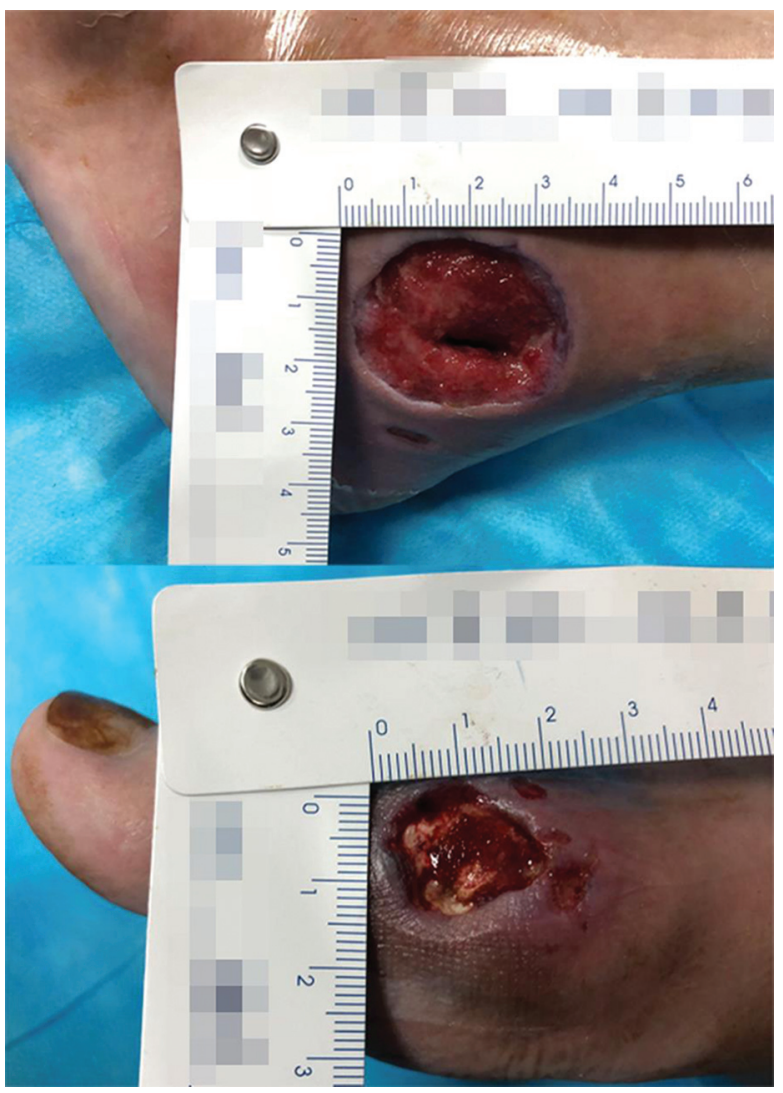

Figure 1. Multiple ulcerations over tophi in one patient
Table 1. Clinical parameters in gout patients with ulceration and without ulceration

\begin{tabular}{lcccc}
\hline *Variable & $\begin{array}{c}\text { Total } \\
(\mathrm{n}=105)\end{array}$ & $\begin{array}{c}\text { Ulceration } \\
(\mathrm{n}=33)\end{array}$ & $\begin{array}{c}\text { Non-ulceration } \\
(\mathrm{n}=72)\end{array}$ & $P$ value \\
\hline Age, years & $54.2 \pm 14.9$ & $61.1 \pm 16.0$ & $51.1 \pm 14.9$ & 0.002 \\
Male, $\mathrm{n}(\%)$ & $102(97.1 \%)$ & $32(97.0 \%)$ & $70(97.2 \%)$ & 0.943 \\
BMI, $\mathrm{kg} / \mathrm{m}^{2}$ & $24.2 \pm 3.6$ & $23.7 \pm 3.5$ & $24.4 \pm 3.7$ & 0.335 \\
Smoking history, $\mathrm{n}(\%)$ & $45(42.9 \%)$ & $17(51.5 \%)$ & $28(38.9 \%)$ & 0.225 \\
History of alcohol intake, $\mathrm{n}(\%)$ & $33(31.4 \%)$ & $11(15.3 \%)$ & $22(30.6 \%)$ & 0.776 \\
Diet control, $\mathrm{n}(\%)$ & $77(73.3 \%)$ & $23(69.7 \%)$ & $54(75.0 \%)$ & 0.568 \\
Glucocorticoid abuse, $\mathrm{n}(\%)$ & $40(38.1 \%)$ & $22(68.8 \%)$ & $18(25.0 \%)$ & $<0.001$ \\
Gout duration, years & $10.9 \pm 6.2$ & $12.5 \pm 7.9$ & $10.2 \pm 5.2$ & 0.208 \\
Tophi duration, years & $4.4 \pm 3.1$ & $6.6 \pm 3.7$ & $3.4 \pm 2.1$ & $<0.001$ \\
Tophi number, $\mathrm{n}$ & $5.2 \pm 4.1$ & $7.6 \pm 4.9$ & $4.1 \pm 3.1$ & 0.003 \\
Hypertension, $\mathrm{n}(\%)$ & $49(46.7 \%)$ & $17(51.5 \%)$ & $32(44.4 \%)$ & 0.500 \\
Diabetes, $\mathrm{n}(\%)$ & $21(20.0 \%)$ & $11(33.3 \%)$ & $10(13.9 \%)$ & 0.021 \\
Cardiovascular disease, $\mathrm{n}(\%)$ & $9(8.6 \%)$ & $4(12.1 \%)$ & $5(6.9 \%)$ & 0.614 \\
Urinary calculus, $\mathrm{n}(\%)$ & $37(35.2 \%)$ & $12(36.4 \%)$ & $25(34.7 \%)$ & 0.870 \\
Serum creatinine, $\mu \mathrm{mol} / \mathrm{L}$ & $109.1 \pm 55.0$ & $122.9 \pm 62.1$ & $102.7 \pm 50.0$ & 0.003 \\
Serum uric acid, $\mu \mathrm{mol} / \mathrm{L}$ & $624.0 \pm 130.7$ & $650.6 \pm 117.6$ & $611.8 \pm 135.3$ & 0.159 \\
ESR, mm/h & $59.2 \pm 39.4$ & $79.9 \pm 37.5$ & $49.7 \pm 36.7$ & $<0.001$ \\
CRP, mg/L & $44.7 \pm 47.1$ & $53.8 \pm 39.9$ & $40.7 \pm 49.8$ & 0.005 \\
GFR, ml/min/1.73 m ${ }^{2}$ & $61.2 \pm 30.0$ & $51.1 \pm 31.1$ & $65.8 \pm 28.6$ & 0.001 \\
\hline
\end{tabular}

n, number.

+ refers to number of the patients.

Table 2. Ulceration characteristics in 33 patients with gout including 38 ulcerations

\begin{tabular}{lc}
\hline Variable & Results \\
\hline Ulceration duration, month & $1.63 \pm 2.32$ \\
Ulceration location & \\
Ankle, n (\%) & $13(34.21 \%)$ \\
MTP, n (\%) & $15(39.47 \%)$ \\
Knee, n (\%) & $1(2.63 \%)$ \\
MCP, n (\%) & $5(13.16 \%)$ \\
PIP, n (\%) & $2(5.26 \%)$ \\
Hip, n (\%) & $1(2.63 \%)$ \\
Elbow, n (\%) & $1(2.63 \%)$ \\
Ulceration size, mm & \\
Length & $32.37 \pm 16.10$ \\
Width & $22.76 \pm 15.28$ \\
Ulceration stage, n (\%) & \\
I & $14(42.4 \%)$ \\
II & $17(51.5 \%)$ \\
III & $2(0.61 \%)$ \\
IV & 0 \\
\hline n, number. &
\end{tabular}

all-cause mortality and cardiovascular mortality. Increased arterial stiffness is an independent marker of cardiovascular diseases and risk predictors. Many studies have shown a significant correlation between uric acid levels and arterial stiffness. Augmentation Index $(\mathrm{Al})$ is an indirect measure of arterial stiffness. Tophi is formed when gout is left untreated for a long time.

Objectives: The aim of this study is to determine whether the presence of tophi could predict an increase in arterial stiffness.

Methods: Between June 2017 and June 2018, augmentation index was measured using SphygmoCor for patients who visited Jeju National University Hospital in South Korea with gout or hyperuricemia. Medical records, laboratory and $\mathrm{Al}$ data were retrospectively analyzed.

Results: One hundred twenty two patients participated in the study and Al was measured. Most $(96.7 \%)$ of the patients were male. At the time of the examination, 99 patients $(81.1 \%)$ were treated with uric acid lowering agent and the mean duration of the disease was 6.9 years. When the patients were divided into two groups according to the presence or absence of Tophi, the average age $(60.2 \pm 11.6$ vs $53.4 \pm 13.2, p=0.023)$ of the patients with Tophi was significantly higher, duration of disease (13.0 \pm 6.5 vs $5.4 \pm 5.4, p=0.000$ ) was longer and the $\mathrm{Al}(28.7 \pm 7.8$ vs $20.7 \pm 10.4$ $p=0.001$ ) was higher. When multiple linear regression analysis was performed to exclude the effects of other variables (DM, HTN, hyperlipidemia, age, BMI, total cholesterol, creatinine), tophi was a predictor of high Al $(b=5.478 ; 95 \% \mathrm{Cl}, 0.343-10.613 ; \mathrm{p}=0.037)$. Multiple logistic regression analysis was performed to determine the predictors of tophi. The duration of disease and $\mathrm{Al} @ 75$ values were significantly predictive of the presence of tophi (Odds ratio 1.113; 95\% Cl, 1.024-1.209; $\mathrm{p}=0.012$ ) Conclusion: This study suggests that the presence of tophi is an independent predictor of increased arterial stiffness in patients with gout and hyperuricemia.

\section{REFERENCES}

[1] Choi HK, Mount DB, Reginato AM. Pathogenesis of gout. Ann Intern Med 2005;143:499-516. 